\title{
PENGGUNAAN LEMAK FLESHING INDUSTRI PENYAMAKAN KULIT UNTUK PEMBUATAN SABUN MANDI
}

\author{
(THE USE OF FAT FROM FLESHING OF LEATHER TANNING \\ FOR BATH SOAP)
}

Ign. Sunaryo ${ }^{1)}$, Sri Sutyasmi ${ }^{1)}$, Widari $^{11}$, Murwati $^{1}$

\begin{abstract}
An experimentation the Use of Fat from Fleshing of Leather Tanning Industry to Produce Bath Soap was aimed to use the fat from fleshing to gain the alternative source of basic material for bath soap, to assist the industry to solve the environmental pollution and increasing the population income. The point to be gainned after finishing this experiment was to find out the problem solving of environmental pollution problem caused by fleshing from leather tanning industry. Goat/sheep fleshing from one of leather tannings in Yogyakarta was collected and had been used as a source of fat. Fat from fleshing was produced by 3 kinds of heating those were coocked, "kukus", and steam. The results of fat analysis showed that the average of saphonification value was 201.01; free faty acid value was $0.86 \%$; acid value was 1.72 and the unsaphonification fat value was $1.44 \%$. The variations of fat used for bath soap manufacture were $55 \%, 60 \%, 65 \%$, $70 \%$ and $75 \%$; whereas the variations of sodium hydrokside were $11,14,17,20$ and 23 , each of which was in parts. The result of this experiment showed that the fat from fleshing could be a source of fat and could be used for bath soap manufacture. In such way, it could be as a pollution problem solving to the industry. The result of bath soap analysis showed that almost all of the variations of fat and sodium hydrokside could meet the SNI 06-3532-1994 about bath soap. Economically point of view showed that the value of producing fat in various regions such as Jabotabek, West Java, Center Java, DIY and East Java would varry from Rp.6,000,000,- to Rp. $200,000,000,-;$ whereas the value of producing bath soap would varry from Rp. $21,000,000$,- Rp.700,000,000,-.
\end{abstract}

Key words: fleshing, fat, soap, environment, tannery, waste management.

\section{PENDAHULUAN}

Limbah padat industri penyamakan kulit mempunyai volume yang sangat besar yaitu sekitar $800 \mathrm{~kg} /$ ton kulit awet garaman. Limbah padat ini berupa sisa trimming, fleshing, split, shaving dan lumpur. Limbah padat yang berupa sisa fleshing volumenya antara $70-230 \mathrm{~kg} /$ ton kulit mentah awet garaman (Jost, 1990).

Besarnya limbah fleshing yang dihasilkan oleh industri penyamakan kulit sangat dipengaruhi oleh kapasitas produksi dari industri yang ada. Kapasitas produksi kulit di Indonesia menurut Diyono (1999), untuk semua jenis kulit dari tahun ke tahun mengalami kenaikan. Lebih lanjut dikatakan bahwa hanya di Jawa saja yang mempunyai potensi untuk produksi kulit. Hal ini terlihat dari total sebanyak 72 industri, ada 69 unit yang berada di P. Jawa. Dari penelitian terdahulu sisa fleshing sudah dimanfaatkan untuk ransum pakan ternak, yang mana dari penelitian ini juga dihasilkan lemak yang tidak sedikit dan belum dimanfaatkan. Kapasitas produksi riel tahun 1999 untuk kulit sapi, kerbau, domba dan kambing di Indonesia

1) Balai Besar Penelitian dan Pengembangan Industri Barang Kulit, Karet dan Plastik 
menurut Diyono (1999) adalah sebagai berikut:

\begin{tabular}{llcc} 
DAERAH/WILAYAH & JENIS KULIT & $\begin{array}{c}\text { JUMLAH INDUSTRI } \\
\text { (Unit) }\end{array}$ & $\begin{array}{c}\text { KAPASITAS RIEL } \\
\text { (juta kaki persegi) }\end{array}$ \\
Jabotabek & Sapi dan kerbau & 23 & 35,40 \\
Jawa Barat & Domba, kambing & 3 & 2,50 \\
\multirow{2}{*}{ Jawa Tengah } & Sapi dan kerbau & 11 & 15,70 \\
& Domba, kambing & 5 & 12,0 \\
Yogyakarta & Sapi dan kerbau & 9 & 7,60 \\
\multirow{2}{*}{ Jawa Timur } & Domba, kambing & 6 & 50 \\
& Sapi dan kerbau & 6 & 1,70 \\
& Domba, kambing & 5 & 7,20 \\
& Sapi dan kerbau & 20 & 54,50 \\
& Domba, kambing & 5 & 17,30
\end{tabular}

Lemak hewan (tallow) merupakan senyawa trigliserida asam karboksilat yang bersifat jenuh dan termasuk golongan ester. Ester mempunyai sifat dapat dipersabunkan dengan menggunakan basa dan menghasilkan sabun. Bahan baku utama dalam pembuatan sabun adalah lemak dan minyak, alkali, serta bahan an organik lainnya. Lemak yang digunakan dalam pembuatan sabun dapat berupa lemak nabati atau lemak hewani. Alkali yang biasa digunakan untuk membuat sabun adalah kaustik soda $(\mathrm{NaOH})$. Sodium hidroksida paling sering digunakan untuk pembuatan sabun dengan mereaksikannya dengan lemak (gliserida dan asam lemak) untuk mendapatkan sabun yang keras yang dapat dibentuk batangan (Bailey, 1945; Shreve, 1967).

Sedangkan bahan anorganik lainnya yang penting dalam pembuatan sabun adalah garam dapur $(\mathrm{NaCl})$, soda abu $\left(\mathrm{Na}_{2} \mathrm{CO}_{3}\right)$, natrium silikat, natrium karbonat $\left(\mathrm{NaHCO}_{3}\right)$. Minyak/lemak ini direaksikan dengan $\mathrm{NaOH}$, sehingga terjadi reaksi penyabunan trigliserida menjadi gliserol dan sabun. Persamaan reaksi yang terjadi jika dianggap gliseridanya mengandung tristearin menurut Made Suladra (1992), adalah sebagai berikut:

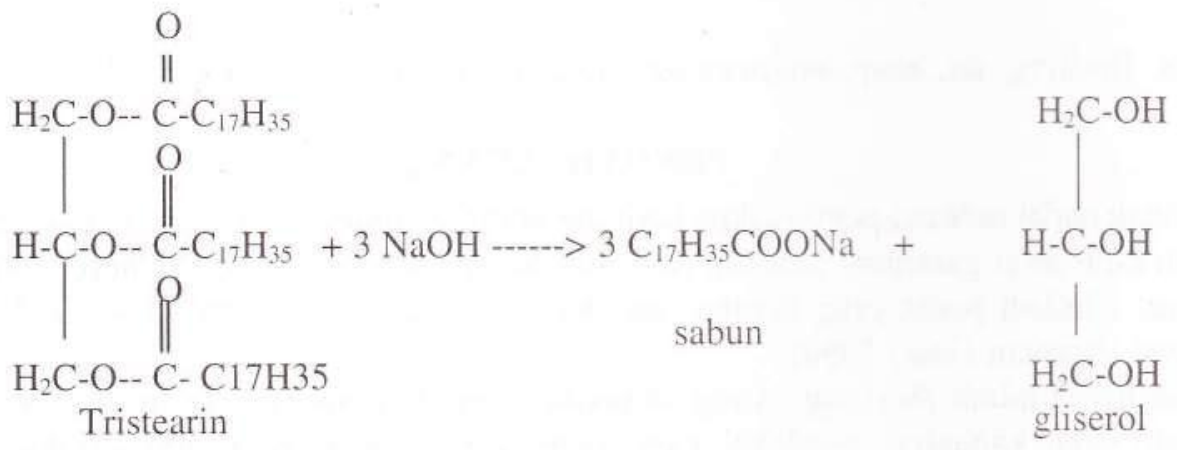

Menurut Bailey (1946); Shreve (1967); dan Made Suladra (1992) ada 3 cara pembuatan sabun yaitu proses dingin, proses panas dan proses pendidihan. Penyabunan pada proses dingin berjalan lambat, karena minyak/lemak dan $\mathrm{NaOH}$ diaduk bersama pada suhu biasa. Sedangkan pada proses panas minyak/lemak dipanaskan hingga $90^{\circ} \mathrm{C}$, kemudian baru ditambahkan larutan $\mathrm{NaOH}$, sehingga reaksinya berjalan lebih cepat. Banyaknya $\mathrm{NaOH}$ yang diperlukan harus dihitung dan dipakai secukupnya. Menurut kedua proses ini hasil samping yang berupa gliserol tidak dapat dipisahkan. Proses pendidihan, minyak/lemak dan larutan $\mathrm{NaOH}$ dididihkan, kemudian 
ditambahkan garam untuk memisahkan sabun dan gliserol serta kelebihan $\mathrm{NaOH}$. Dengan cara ini diperoleh gliserol, sebagai hasil samping.

Dalam industri sabun, $\mathrm{NaCl}$ berfungsi sebagai pemisah sabun dalam air dan gliserol. Untuk mendapatkan sabun dengan kwalitas baik, garam yang dibebaskan harus bebas dari senyawa besi, kalsium, dan magnesium. Dalam proses pembuatan sabun, garam dapat digunakan dalam bentuk serbuk atau kristal. Penelitian ini bertujuan untuk memanfaatkan limbah fleshing sebagai bahan alternatif untuk pembuatan sabun, memecahkan masalah pencemaran, menumbuhkan bidang usaha baru yang dapat meningkatkan pendapatan masyarakat.

\section{BAHAN DAN METODE PENELITIAN}

Limbah fleshing diambil dari salah satu industri penyamakan kulit di Yogyakarta, yang selanjutnya diproses penetralan yang meliputi: pencucian, pembuangan kapur, penghilangan sulfida, dan pengambilan lemak.

Lemak dari sisa fleshing diambil dengan tiga cara pemanasan yakni dengan cara direbus (fleshing digodok bersama air dan lemak mengapung di permukaan air), dikukus (fleshing digodok terpisah dengan air oleh saringan, lemak yang terjadi akan mengapung di permukaan air) dan disteam (fleshing dipanasi dengan uap air, lemak yang terjadi dialirkan ke alat penampung).

Hanya lemak yang diperoleh dengan cara steam saja, yang diuji untuk mengetahui angka penyabunan, angka asam, asam lemak bebas, lemak tak tersabunkan, kadar air dan kadar kotoran. Selanjutnya lemak dibuat sabun dengan mencampurkannya dengan alkali dan bahan-bahan lain dalam kondisi panas. Lemak yang diperoleh kemudian dicampur dengan alkali dan bahan-bahan tambahan lain seperti gliserin, alkohol, pewarna, pewangi, dalam kondisi panas, kemudian dicetak dan didinginkan sehingga diperoleh sabun.

Sabun yang dibuat pada penelitian ini adalah sabun mandi batangan dengan variasi lemak dan variasi $\mathrm{NaOH}$. Variasi lemak dalam pembuatan sabun mandi adalah $55 \%, 60 \%, 65 \%, 70 \%$ dan $75 \%$, sedang variasi $\mathrm{NaOH}$ yang digunakan adalah $11,14,17,20$ dan 23 dengan masingmasing dalam bagian.

Sabun hasil penelitian diuji sesuai SNI 06-3532-1994: tentang sabun mandi dengan parameter: angka penyabunan, angka asam, asam lemak bebas, lemak tak tersabunkan, kadar kotoran, kadar air dan kadar lemak. Selanjutnya kwalitas sabun mandi hasil penelitian dibandingkan dengan sabun yang diperoleh di pasar.

\section{HIPOTESIS}

Dengan dimanfaatkannya limbah fleshing dari industri penyamakan kulit sebagai sumber penghasil lemak untuk pembuatan sabun, maka permasalahan pencemaran yang diakibatkannya dapat teratasi dan bisa diperoleh peningkatan pendapatan masyarakat.

\section{HASIL DAN PEMBAHASAN}

\section{Pengambilan lemak dari sisa fleshing.}

Hasil proses pengambilan lemak dari sisa fleshing yang dilaksanakan dengan cara steam, rebus dan kukus, dapat dilihat pada Tabel 1.Dari tabel 1 dapat dilihat bahwa secara keseluruhan banyaknya lemak yang diperoleh dengan ketiga cara tersebut di atas tidak jauh berbeda. Namun demikian ada kecenderungan bahwa dengan cara steam dapat menghasilkan jumlah lemak yang lebih tinggi dibanding dengan cara rebus dan kukus. 
Tabel 1. Hasil pengambilan lemak dengan cara steam, rebus dan kukus.

\begin{tabular}{|c|c|c|c|c||}
\hline NO & WAKTU & \multicolumn{3}{|c|}{ CARA PEMANASAN } \\
\hline & Menit & $\begin{array}{c}\text { STEAM } \\
\text { (gr/kg fleshing } \\
\text { basah) }\end{array}$ & $\begin{array}{c}\text { REBUS } \\
\text { (gr/kg fleshing } \\
\text { basah) }\end{array}$ & $\begin{array}{c}\text { KUKUS } \\
\text { (gr/kg fleshing } \\
\text { basah) }\end{array}$ \\
\hline 1. & 15 & 48,4 & 44 & 62 \\
\hline 2. & 30 & 57,4 & 59,2 & 42 \\
\hline 3. & 74 & 76,8 & 74,8 & 73 \\
\hline 4. & 60 & 85 & 61 & 62 \\
\hline
\end{tabular}

Pemanasan fleshing dengan cara kukus selama 15 menit, menghasilkan jumlah lemak tertinggi dibanding dengan steam dan rebus. Lemak yang diperoleh dengan cara ini masih mengandung air dan kelihatan kotor. Pemanasan dengan cara rebus selama 30 menit dapat menghasilkan jumlah lemak tertinggi yakni 59,2 gr. Lemak yang diperoleh dengan cara kukus mempunyai sifat yang serupa dengan cara rebus yakni kurang bersih dan warnanya suram/tidak jernih. Pemanasan selama 45 dan 60 menit dengan cara steam dapat diperoleh jumlah lemak tertinggi yakni 76,8 gr dan $85 \mathrm{gr}$. Lemak yang diperoleh terlihat lebih bersih dan cerah. Dengan demikian dapat dikatakan bahwa pengambilan lemak dengan cara steam dengan waktu pemanasan yang sama dapat diperoleh jumlah lemak yang lebih banyak, dan warnanya lebih cerah dan bersih dibanding pemanasan dengan cara rebus dan kukus. Hal ini disebabkan karena lemak yang diperoleh dari proses steam seluruhnya bisa ditampung. Sebaliknya lemak yang diperoleh dengan cara rebus dan kukus tidak bisa seluruhnya terambil karena sebagian masih tercampur dalam fleshing dan air. Disamping itu diduga pemanasan dengan cara steam bisa mendapatkan suhu yang efektif untuk mencairkan lemak, karena tidak ada uap air yang keluar sehingga panas dalam steam dapat dipertahankan. Pemanasan dengan cara rebus dan kukus jumlah lemak terbanyak diperoleh pada waktu pemanasan selama 45 menit, sehingga dapat dikatakan untuk cara pemanasan rebus dan kukus penggunaan waktu pemanasan yang lebih lama dari 45 menit sudah tidak efektif.

Menurut Shreve (1967), pengambilan lemak meliputi pemurnian (refining), pemutihan (bleaching), dehidrogenerating dan penghilangan bau (deodorizing). Namun demikian dijelaskan lebih lanjut bahwa tidak ada metode khusus untuk proses pengambilan lemak ini. Sedangkan metode untuk pengambilan lemak yang banyak dipakai ialah dengan sistem steam. Lemak yang diperoleh dengan cara inilah yang digunakan untuk percobaan pembuatan sabun mandi dalam penelitian ini.

\section{Hasil uji lemak fleshing.}

Hasil uji lemak dari limbah fleshing dapat dilihat pada Tabel 2. 
Tabel 2. Hasil uji lemak dari limbah fleshing

\begin{tabular}{|c|l|r|r|c|l|}
\hline \multirow{2}{*}{ NO. } & \multicolumn{1}{|c|}{ PARAMETER } & \multicolumn{4}{|c|}{ U L A N G A N } \\
\cline { 3 - 6 } & & \multicolumn{1}{c|}{ I } & \multicolumn{1}{c|}{ II } & III & Rerata \\
\hline 1. & Angka penyabunan & 201,87 & 202,2 & 198,96 & 201,01 \\
2. & Angka asam & 1,71 & 1,72 & 1,74 & 1,72 \\
3. & Asam lemak bebas (\%) & 0,86 & 0,86 & 0,87 & 0,86 \\
4. & Lemak tak tersabunkan (\%) & 1,68 & 1,26 & 1,37 & 1,44 \\
5 & Kadar kotoran (\%) & 0,38 & 1,15 & 0,75 & 0,76 \\
6. & Kadar Air (\%) & 2,13 & 3,61 & 2,57 & 2,77 \\
7. & Kadar Lemak (\%) & 97,49 & 95,24 & 96,68 & 96,47 \\
\hline
\end{tabular}

Dari Tabel 2. dapat dilihat bahwa rerata hasil uji dari beberapa parameter uji adalah: angka penyabunan cukup tinggi yakni 201,01 ; angka asam kecil $(1,72)$; asam lemak bebas kecil $(0,86 \%)$; lemak tak tersabunkan juga kecil yakni $1,44 \%$; sehingga lemak hasil isolasi dari sisa fleshing cukup layak untuk dibuat sabun. Pembuatan sabun selama pra penelitian menggunakan proses dengan resep seperti pada metoda atau menurut resep dari Made Suladra, (1992). Sabun mandi hasil penelitian dengan variasi lemak dan variasi natrium hidroksida $(\mathrm{NaOH})$, diuji dengan parameter sesuai dengan SNI 06-3532-1994 tentang sabun mandi.

\section{Pengujian Sabun Mandi}

a. Pengujian sabun mandi yang dibuat dengan variasi lemak.

Hasil uji sabun mandi dengan variasi lemak dapat dilihat pada Tabel 3.

Tabel 3. Hasil pengujian sabun mandi dengan variasi lemak.

\begin{tabular}{|c|c|c|c|c|c|c|c|}
\hline \multirow[t]{2}{*}{ NO } & \multirow[b]{2}{*}{ PARAMETER } & \multicolumn{5}{|c|}{ VARIASI LEMAK } & \multirow[b]{2}{*}{ SNI } \\
\hline & & $\begin{array}{c}\text { F1 } \\
\text { Rerata }\end{array}$ & $\begin{array}{c}\text { F2 } \\
\text { Rerata }\end{array}$ & $\begin{array}{c}\text { F3 } \\
\text { Rerata }\end{array}$ & $\begin{array}{c}\text { F4 } \\
\text { Rerata }\end{array}$ & $\begin{array}{c}\text { F5 } \\
\text { Rerata }\end{array}$ & \\
\hline 1. & Kadar air \% & 14,97 & 10,90 & 14,92 & 14,79 & 13,02 & Maks15 \\
\hline 2. & Jumlah as. Lemak \% & 72,19 & 72,35 & 72,86 & 75,72 & 75,91 & $>70 \%$ \\
\hline 3. & $\begin{array}{l}\text { Alkali bebas \% } \\
\text { sebagai } \mathrm{NaOH}\end{array}$ & 0,17 & 0,17 & 0,10 & 0,10 & 0,11 & $\begin{array}{l}\text { Maks } \\
0,14\end{array}$ \\
\hline 4. & $\begin{array}{l}\text { As. Lemak \% } \\
\text { bebas/netral }\end{array}$ & 1,01 & 0,97 & 0,49 & 0,51 & 0,61 & $<2,5 \%$ \\
\hline 5. & Minyak mi neral & neg & neg & neg & neg & neg & neg \\
\hline
\end{tabular}

Keterangan: $\quad \mathrm{F} 1=$ penggunaan lemak $55 \%$ dan minyak kelapa $20 \%$

$\mathrm{F} 2$ = penggunaan lemak $60 \%$ dan minyak kelapa $15 \%$

$\mathrm{F} 3$ = penggunaan lemak $65 \%$ dan minyak kelapa $10 \%$

F4 = penggunaan lemak $70 \%$ dan minyak kelapa $5 \%$

F5 = penggunaan lemak $75 \%$ dan minyak kelapa $0 \%$ 
Dari Tabel 3 tersebut dapat diketahui bahwa semua variasi perlakuan dapat memenuhi SNI 06-3532-1994, kecuali alkali bebas pada perlakuan dengan variasi lemak F1(55\%); dan F2 (60\%), untuk itulah maka diperlukan variasi $\mathrm{NaOH}$.

Hasil analisa statistik untuk setiap parameter uji adalah sebagai berikut:

\section{- Kadar air}

Berdasarkan perhitungan statistik, dapat diketahui bahwa tidak ada perbedaan yang nyata dari masing-masing variasi perlakuan dengan $\mathrm{F}$ hitung $=2,89$ dan $\mathrm{F}$ tabel $=3,79$. Kadar air untuk semua variasi dapat memenuhi SNI 06-3532-1994. Dengan demikian, ditinjau dari kadar air maka dapat dikatakan bahwa semua resep bisa digunakan untuk pembuatan sabun mandi. Kadar air tertinggi diperoleh dari variasi penggunaan lemak $55 \%$ dengan rerata sebesar $14,97 \%$. Nilai kadar air terendah diperoleh dari penggunaan lemak $60 \%$ dengan rerata sebesar $10,90 \%$. Tinggi rendahnya kadar air dipengaruhi oleh komposisi lemak fleshing dan minyak kelapa yang digunakan. Unsur utama lemak dari sisa fleshing antara lain gliseril tristearat termasuk lemak yang terbentuk dari asam jenuh yang dalam rantai karbonnya tidak ada ikatan rangkap, jadi bersifat stabil. Sedangkan minyak kelapa mengandung unsur yang dominan adalah gliseril trioleat termasuk lemak/minyak yang terbentuk dari asam tak jenuh, yang di dalam rantai karbonnya terdapat ikatan rangkap yang bersifat tidak stabil (reaktif).

Adanya ikatan rangkap dalam minyak kelapa yaitu gliseril trioleat akan menimbulkan sifat mudah teroksidasi, dan terhidrolisa (adisi dengan $\mathrm{H}_{2} \mathrm{O}$ ). Dengan demikian pada menggunakan variasi jumlah minyak kelapa tertinggi ( $20 \%$ ), akan mengikat $\mathrm{H}_{2} \mathrm{O}$ paling banyak, sehingga menyebabkan kadar air dalam sabun paling tinggi.

\section{- Jumlah asam lemak.}

Tidak terdapat perbedaan yang nyata dari masing-masing variasi perlakuan dengan $\mathrm{F}$ hitung $=$ 1,80 dan Ftabel $=3,79$. Jumlah asam lemak dari setiap variasi menunjukkan nilai di atas $70 \%$, dan memenuhi SNI 06-3532-1994. Berdasarkan nilai jumlah asam lemak tersebut, maka semua resep bisa digunakan untuk pembuatan sabun mandi. Ada kecenderungan semakin besar penggunaan lemak, maka jumlah asam lemak yang diikat menjadi sabun semakin tinggi. Nilai jumlah asam lemak berkisar antara 70,69-77,07\%, sedangkan jumlah asam lemak menurut SNI adalah sebesar $\geq 70 \%$.

Bila asam lemak yang tersabunkan semakin besar, maka jumlah asam lemak makin tinggi dan persabunan makin sempurna (makin baik). Dari hasil uji dapat dilihat bahwa makin banyak jumlah minyak kelapa yang digunakan, proses penyabunan makin baik (jumlah asam lemak makin tinggi). Hal ini disebabkan karena lemak fleshing (gliseril tristearat) bersifat stabil, sehingga kurang reaktif, sedangkan minyak kelapa (gliseril trioleat) bersifat tidak stabil. Jadi dalam hal ini minyak kelapa akan lebih mudah tersabunkan, sehingga kadar/jumlah asam lemaknya akan semakin tinggi.

\section{- As. lemak bebas dan atau lemak netral.}

Terdapat perbedaan yang sangat nyata $\mathrm{P}<0,01$ dari variasi penggunaan lemak $55 \%$ dan 60 $\%$ terhadap variasi penggunaan lemak lainnya. Nilai asam lemak bebas/netral dari semua variasi berkisar antra 0,46-1,08\%, dan dapat memenuhi SNI-06-3532-1994 yakni kurang dari $2,5 \%$. Semakin kecil nilai asam lemak bebas yang terdeteksi, berarti semakin besar lemak yang tersabunkan. Hal demikian berarti pula reaksi penyabunan dalam pembuatan sabun tersebut semakin baik. Rata-rata nilai asam lemak tertinggi dijumpai pada variasi penggunaan lemak $55 \%$ dengan minyak kelapa $20 \%$ yakni sebesar $1,005 \%$, sedangkan nilai terendah dijumpai pada variasi penggunaan lemak $65 \%$ dengan minyak kelapa $10 \%$ yakni sebesar $0,49 \%$. 
Dari hasil pengujian dapat diketahui bahwa semakin banyak jumlah minyak kelapa yang digunakan, menjadikan jumlah lemak bebas semakin tinggi, hal ini disebabkan karena minyak kelapa merupakan gliseril tri oleat yang dalam rantai karbonnya ada ikatan rangkap (tak jenuh), menyebabkan tidak stabil, mudah bereaksi dan akan teroksidasi, sehingga diperoleh asam bebas.

- Alkali bebas dihitung sebagai $\mathrm{NaOH}$.

Dari analisa statistik ternyata tidak terdapat perbedaan yang nyata $\mathrm{P}<0,05$ dari masingmasing variasi perlakuan, $\mathrm{F}$ hitung $=2,5$ dan $\mathrm{F}$ tabel $=3,79$. Nilai tertinggi diperoleh dari variasi penggunaan lemak $55 \%$ yakni sebesar $0,17 \%$ dan terendah dari variasi penggunaan lemak $70 \%$ yakni sebesar $0,09 \%$.

Di samping itu dapat pula diketahui bahwa nilai seluruh parameter dari formula F5, dengan kandungan lemak 75\% dapat memenuhi SNI 06-3532-1994. Atas dasar itu, maka variasi F5 tersebut digunakan sebagai dasar untuk penentuan variasi $\mathrm{NaOH}$. Alkali bebas ditunjukkan sebagai $\mathrm{NaOH}$, hal ini karena alkali yang digunakan adalah $\mathrm{NaOH}$ untuk membuat sabun mandi dalam bentuk padat. Reaksi penyabunannya adalah peruraian ester (lemak/minyak) dengan menggunakan basa. Sehingga sabun mandi hasil percobaan yang berbentuk padat tersebut mengandung alkali bebas (\%) yang ditunjukkan sebagai $\mathrm{NaOH}$.

\section{b. Pengujian sabun mandi dengan variasi $\mathrm{NaOH}$}

Adapun formulasi yang digunakan untuk pembuatan sabun mandi dengan variasi $\mathrm{NaOH}$ dapat dilihat pada Tabel 4 .

Tabel 4. Resep sabun mandi dengan variasi $\mathrm{NaOH}$

\begin{tabular}{|c|c|c|c|c|c|}
\hline PARAMETER & N11 & N14 & N17 & $\mathrm{N} 20$ & N23 \\
\hline Lemak (bagian) & 75 & 75 & 75 & 75 & 75 \\
\hline Minyak kelapa (bagian) & 5 & 5 & 5 & 5 & 5 \\
\hline Gliserin(bagian) & 5 & 5 & 5 & 5 & 5 \\
\hline Kaustic soda $\mathrm{NaOH}$ (bagian) & 11 & 14 & 17 & 20 & 23 \\
\hline Water glass (bagian) & 1 & 1 & 1 & 1 & 1 \\
\hline Alkohol (bagian) & 1 & 1 & 1 & 1 & 1 \\
\hline Pewangi (bagian) & 1 & 1 & 1 & 1 & 1 \\
\hline (bagian) & 1 & 1 & 1 & 1 & 1 \\
\hline
\end{tabular}

Dari Tabel 4 tersebut diketahui bahwa pemakaian variasi $\mathrm{NaOH}$ adalah mulai dari 11, 14, 17, 20 dan 23, masing-masing dalam bagian. Sedangkan banyaknya lemak fleshing yang digunakan adalah tetap yakni 75 bagian. Dasar pemikiran penggunaan variasi $\mathrm{NaOH}$ ini ialah karena sabun mandi hasil percobaan dengan variasi lemak, mempunyai penampilan yang tidak seragam. Ada yang keras sekali dan ada yang lembek sekali. Sehingga perlu dilakukan variasi $\mathrm{NaOH}$. Hasil pengujian terhadap sabun mandi yang dibuat dengan variasi $\mathrm{NaOH}$ dapat dilihat pada Tabel 5 . 
Tabel 5. Hasil pengujian sabun mandi yang dibuat dengan variasi $\mathrm{NaOH}$

\begin{tabular}{|c|l|c|c|c|c|c|c|}
\hline \multirow{2}{*}{ NO } & \multirow{2}{*}{ PARAMETER } & \multicolumn{7}{|c|}{ V A R I S I N a H } & \\
\cline { 3 - 8 } & & N11 & N14 & N17 & N20 & N23 & SNI \\
\cline { 2 - 8 } & Rerata & Rerata & Rerata & Rerata & Rerata & \\
\hline 1. & Kadar air \% & 10,11 & 13,41 & 13,86 & 5,71 & 10,50 & Maks 15 \\
\hline 2. & $\begin{array}{l}\text { Jumlah asam lemak } \\
\%\end{array}$ & 77,75 & 71,92 & 75,45 & 70,56 & 82,73 & $>70 \%$ \\
\hline 3. & $\begin{array}{l}\text { Alkali bebas \% } \\
\text { sebagai NaOH }\end{array}$ & 0,18 & 0,20 & 0,12 & 0,17 & 0,02 & Maks 0,14 \\
\hline 4. & $\begin{array}{l}\text { Asam lemak \% } \\
\text { bebas/netral }\end{array}$ & 0,80 & 0,68 & 0,61 & 0,51 & 0,55 & $<2,5 \%$ \\
\hline 5. & $\begin{array}{l}\text { Minyak mineral } \\
\text { neg }\end{array}$ & neg & neg & neg & neg & neg \\
\hline
\end{tabular}

Keterangan: N11 s/d N23 adalah penggunaan $\mathrm{NaOH}$ dari 11 bag. ; 14 bag.; 17 bag.; 20 bag.; dan 23 bag.

Dari Tabel 5. tersebut dapat diketahui bahwa hampir semua hasil uji dengan variasi $\mathrm{NaOH}$ $11,14,17,20$ dan 23 bagian, dapat memenuhi SNI 06-3532-1994, kecuali alkali bebas yang dihitung sebagai $\mathrm{NaOH}$ dengan pemakaian $\mathrm{NaOH} 11$ dan 14 bagian (F1 dan F2). Secara umum berdasarkan hasil analisa, sabun mandi yang terbaik adalah yang dibuat dengan variasi lemak 75 bagian, minyak kelapa 5 bagian, gliserin 5 bagian, $\mathrm{NaOH}$ sebasar 23 bagian, water glass 1 bagian, alkohol 1 bagian, pewangi 1 bagian dan $\mathrm{NaCl} 1$ bagian. Hal ini sama dengan variasi yang digunakan untuk pembuatan sabun cuci yakni sebesar 23 bagian seperti dikemukakan oleh Sutyasmi, dkk., 2002. Tetapi pada kenyataannya sabun mandi yang dibuat dengan variasi $\mathrm{NaOH}$ 23 bagian tersebut, tampak keras dan bila digunakan untuk mencuci tangan terasa gatal di kulit. Hal ini menunjukkan bahwa pemakaian $\mathrm{NaOH}$ berlebihan, sedangkan sabun mandi yang dibuat dengan variasi $\mathrm{NaOH} \mathrm{17 \%}$, di samping hasil ujinya dapat memenuhi SNI 06-3532-1994, bila digunakan untuk mencuci tangan terasa enak (tidak gatal).

Hasil analisa statistik untuk setiap parameter uji menunjukkan:

\section{- Kadar Air.}

Ada perbedaan yang sangat nyata $(\mathrm{P}<0,01)$ antara variasi penggunaan $\mathrm{NaOH} 20$ bagian dengan variasi perlakuan lainnya. Rata-rata nilai kadar air tertinggi dari variasi penggunaan $\mathrm{NaOH} 17$ bagian yakni sebesar 13,86\% dan terendah dijumpai pada variasi penggunaan $\mathrm{NaOH}$ 20 bagian yakni sebesar 5,71 \%. Dikatakan oleh Bailey (1945), bahwa walaupun dalam pembuatan sabun digunakan air sebesar $32-33 \%$, namun kadar air dalam sabun yang baik tidak boleh lebih dari $15 \%$.

\section{- Jumlah asam Lemak.}

Terdapat perbedaan yang sangat nyata $(\mathrm{P}<0,01)$ antara variasi penggunaan $\mathrm{NaOH} 23$ bagian dengan variasi perlakuan lainnya. Rata-rata nilai asam lemak tertinggi diperoleh dari penggunaan $\mathrm{NaOH} 23$ bagian yakni sebesar $82,73 \%$, sedangkan terendah dari penggunaan $\mathrm{NaOH}$ 20 bagian yakni sebesar $70,57 \%$.

\section{- Alkali bebas dihitung sebagai $\mathrm{NaOH}$.}

Terdapat perbedaan yang sangat nyata $(\mathrm{P}<0,01)$ dari variasi perlakuan penggunaan $\mathrm{NaOH}$ 23 bagian terhadap variasi penggunaan $\mathrm{NaOH}$ lainnya. Rata-rata nilai tertinggi diperoleh dari variasi penggunaan $\mathrm{NaOH} 14$ bagian yakni sebesar $0,19 \%$ dan terendah dari variasi penggunaan $\mathrm{NaOH} 20$ bagian yakni sebesar $0,02 \%$. 


\section{- Asam lemak bebas dan atau lemak netral.}

Terdapat perbedaan yang sangat nyata, $(\mathrm{P}<0,01$ ) dengan $\mathrm{F}$ hitung 9,0 dan $\mathrm{F}$ tabel 6,11 . Perbedaan yang sangat nyata dari variasi penggunaan $\mathrm{NaOH} 11$ bagian terhadap variasi $\mathrm{NaOH}$ lainnya. Rata-rata nilai asam lemak bebas tertinggi dari variasi penggunaan $\mathrm{NaOH} 11$ bagian, sebesar $0,80 \%$ dan terendah dari variasi penggunaan $\mathrm{NaOH} 20$ bagian, sebesar 0,51\%.

\section{c. Pengujian sabun mandi yang diperoleh di pasar.}

Di samping sabun mandi hasil percobaan, dilakukan juga pengujian tehadap sabun mandi yang dibeli di pasar sebagai pembanding. Nilai pengujian sabun mandi yang dibeli di pasar disajikan pada Tabel 6.

Dari Tabel 6 dapat diketahui bahwa nilai dari hampir semua parameter uji dapat memenuhi SNI 06-3532-1994, kecuali parameter alkali bebas.

Tabel 6. Hasil pengujian sabun mandi yang dibeli dipasar

\begin{tabular}{|l|l|l|l||}
\hline No. & PARAMETER & $\begin{array}{c}\text { HASIL UJI } \\
(\%)\end{array}$ & $\begin{array}{c}\text { SNI 06-3532-1994 } \\
(\%)\end{array}$ \\
\hline 1. & Kadar air & 8,16 & maks 15 \\
\hline 2. & Jumlah asam lemak & 71,63 & $>70 \%$ \\
\hline 3. & Alkali bebas dihitung sebagai NaOH & 0,12 & maks 0,1 \\
\hline 4. & As. lemak bebas dan atau lemak netral & 0,94 & $<2,5$ \\
\hline 5. & Minyak mineral & negatif & negatif \\
\hline
\end{tabular}

Kalau dibandingkan dengan nilai hasil uji sabun mandi hasil penelitian, maka dapat diketahui bahwa kadar air sabun mandi yang diperoleh dari pasar lebih rendah. Kandungan asam lemak sabun hasil penelitian lebih tinggi dibanding dengan sabun yang diperoleh dari pasar. Dengan demikian sabun mandi yang ada di pasar yang banyak dikonsumsi oleh masyarakat ternyata juga belum tentu dapat memenuhi SNI 06-3532-1994. Dengan lain perkataan sabun hasil penelitian secara teoritis sudah dapat masuk pasaran, karena sudah dapat memenuhi SNI 06-3532-1994 dan secara kwalitas tidak jauh berbeda dengan sabun mandi yang diperoleh di pasaran.

\section{Analisis Ekonomi}

Analisis ekonomi tentang pemanfaatan lemak fleshing untuk pembuatan sabun mandi ini meliputi: potensi produksi fleshing dan lemak, perhitungan ekonomi harga lemak dan perhitungan ekonomi harga sabun.

Untuk mendapatkan gambaran tentang keuntungan secara ekonomi, maka penulis sengaja hanya mengambil contoh produksi lemak dari kulit sapi dan kerbau saja, dengan pemikiran bahwa produksi kulit sapi dan kerbau jauh lebih besar dan menghasilkan fleshing dan lemak yang lebih besar dibanding dengan kulit domba/ kambing.

\section{a. Potensi produksi fleshing}

Potensi industri penyamakan kulit sebagian besar berada di pulau Jawa. Dari total sebanyak 72 industri seperti yang disampaikan oleh Diyono (1999), maka hanya 3 unit yang berada di luar pulau Jawa. Sedangkan yang ada di pulau Jawa tersebar di wilayah Jabotabek 23 unit dengan 
kapasitas produksi riel dengan satuan kaki persegi adalah sebesar 35,40 juta; Jawa Barat 11 unit dengan kapasitas produksi riel 15,70 juta; Jawa Tengah 9 unit dengan kapasitas produksi riel (7,60 juta); Yogyakarta 6 unit (1,70 juta); Jawa Timur 20 unit dengan kapasitas produksi riel sebesar (54,50 juta). Brotomuljono, dkk.(1986), menjelaskan bahwa konversi untuk luas kulit jadi dalam kaki persegi $\left(\mathrm{ft}^{2}\right)$ : berat kulit mentah awet garam, untuk kulit kecil $(\mathrm{kg})=1: 0,54$. Sedangkan volume limbah fleshing menurut Jost (1990) berkisar antara $70-230 \mathrm{~kg} / \mathrm{ton}$.

Dengan demikian, setelah kapasitas produksi kulit jadi dalam satuan kaki persegi, dikonversikan ke berat kulit mentah awet garam dalam kilogram, kemudian jumlah limbah fleshing dihitung menurut Jost (1990), akan diketahui besarnya potensi minimal produksi limbah fleshing sebagai berikut:

Jabotabek
Minimal produksi fleshing
Jawa Barat
Minimal produksi fleshing
Jawa Tengah
Minimal produksi fleshing
Yogyakarta
Minimal produksi fleshing
Jawa Timur
Minimal produksi fleshing

$$
\begin{aligned}
& =\quad 35.400 .000 \times 0.54=19.116 \text { ton. } \\
& =19.116 \times 70=1.338,120 \text { ton. } \\
& =\quad 15.700 .000 \times 0.54=8.478 \text { ton. } \\
& =\quad 8.478 \times 70=593,460 \text { ton. } \\
& =7.600 .000 \times 0,54=4.104 \text { ton. } \\
& =\quad 4.104 \times 70=287,280 \text { ton. } \\
& =\quad 1.700 .000 \times 0,54=918 \text { ton. } \\
& =\quad 918 \times 70=64,260 \text { ton. } \\
& =54.500 .000 \times 0.54=29.430 \text { ton. } \\
& =29.430 \times 70=2.060,100 \text { ton } \text {. }
\end{aligned}
$$

\section{b. Potensi produksi lemak}

Berdasarkan hasil produksi fleshing tersebut, maka dapat diprediksi volume lemak yang akan diperoleh. Dari hasil penelitian dapat diketahui bahwa dengan cara steam, dalam waktu satu jam dapat dihasilkan $0,085 \mathrm{~kg}$ lemak atau 85 gram per $\mathrm{kg}$ fleshing. Kalau satu hari bekerja selama 8 jam, per jam memproses fleshing sebanyak $1 \mathrm{~kg}$, maka $8 \mathrm{~kg}$ fleshing bisa menghasilkan 680 gram lemak, yang bisa untuk membuat sabun mandi sekitar 100 batang, karena hasil penelitian menunjukkan bahwa kebutuhan lemak untuk memproduksi satu batang sabun mandi seberat 100 gram adalah berkisar antara $60 \%-75 \%$. Dengan demikian potensi wilayah di P. Jawa untuk memproduksi lemak dari limbah fleshing kulit sapi dan kerbau dapat diuraikan sebagai berikut:

- Per kilogram fleshing menghasilkan 85 gram lemak dalam waktu satu jam.

- Andaikan per hari bekerja selama 8 jam dan per jam bisa memproses $100 \mathrm{~kg}$ fleshing, maka dalam satu ahari ada $800 \mathrm{~kg}$ fleshing yang diproses dan menghasilkan lemak $68 \mathrm{~kg}$ atau $85 \mathrm{~kg}$ lemak per ton fleshing.

- Lemak sebanyak $85 \mathrm{~kg}$ cukup untuk membuat sabun mandi sebanyak 1.133 - 1.400 batang (satu batang dengan berat total $100 \mathrm{gr}$, dibutuhkan lemak sebanyak 60 - $75 \mathrm{gr}$ ).

- Produksi minimal lemak dari kulit sapi dan kerbau per wilayah adalah:

$$
\begin{array}{llll}
>\text { Jabotabek } & =1.338,120 \times 85 \mathrm{~kg} & =113.740,200 \mathrm{~kg} \\
>\text { Jawa Barat } & =593,460 \times 85 \mathrm{~kg} & =50.444,100 \mathrm{~kg} \\
>\text { Jawa Tengah } & =287,280 \times 85 \mathrm{~kg} & = & 24.418,800 \mathrm{~kg} \\
>\text { Yogyakarta } & =64.260 \times 85 \mathrm{~kg} & & =5.462,100 \mathrm{~kg} \\
>\text { Jawa Timur } & =2.060,100 \times 85 \mathrm{~kg} & & =175.108,500 \mathrm{~kg}
\end{array}
$$

Untuk mendapatkan gambaran secara kasar nilai lemak dari limbah fleshing berdasarkan data a dan b di atas, maka penulis mengikuti informasi yang disajikan oleh Sri Sutyasmi, dkk. (2001), menyebutkan bahwa harga jual per kilogram lemak dari limbah fleshing ini adalah sebesar Rp. 1250,-. Dengan demikian nilai produksi lemak fleshing untuk berbagai wilayah di P. Jawa adalah: 


\begin{tabular}{|c|c|c|}
\hline & 0 kg x Rp. 1.2 & \\
\hline & $=50.444,100 \mathrm{~kg} \times$ Rp. $1.250,-/ \mathrm{kg}$ & $5,-$ \\
\hline & $=24.418,800 \mathrm{~kg} \times \mathrm{Rp} .1 .250,-/ \mathrm{kg}$ & $=\mathrm{Rp}$ \\
\hline & $=5.462,100 \mathrm{~kg} \times \mathrm{Rp} .1 .250,-/ \mathrm{kg}$ & $\begin{array}{l}=\mathrm{Rp} . \\
=\mathrm{Rp} .\end{array}$ \\
\hline
\end{tabular}

\section{c. Potensi produksi sabun}

Setelah dilakukan perhitungan secara kasar, maka dapat diketahui bahwa harga sabun mandi hasil penelitian ialah sebesar Rp. 360,-/batang dibulatkan menjadi Rp.400,-. Untuk satu batang sabun mandi seberat 100 gr, dibutuhkan lemak berkisar antara 60 - 75 gr. Dengan demikian apabila lemak fleshing dari butir c di atas dibuat sabun, maka akan diperoleh nilai sabun tersebut sebagai berikut:

- Untuk satu kilogram lemak bisa digunakan untuk membuat sabun sebanyak minimal 10 batang seharga Rp.400,- x 10 = Rp. 4.000,-

- Untuk satu ton lemak bisa digunakan untuk membuat sabun mandi minimal sebanyak 10.000 batang, dengan harga Rp. 4.000.000,-

- Apabila harga sabun di berbagai daerah sama, maka akan diperoleh nilai produksi sebesar:

$\begin{array}{lll}>\text { Jabotabek } & =113.740,2 \mathrm{~kg} \times \mathrm{Rp} .4 .000,-/ \mathrm{kg} & =\mathrm{Rp} .454 .960 .800,,^{-}- \\ >\text {Jawa Barat } & =50.444,1 \mathrm{~kg} \times \mathrm{Rp} .4 .000,-/ \mathrm{kg} & =\mathrm{Rp} 201.776 .400,- \\ >\text { Jawa Tengah } & =24.418,8 \mathrm{~kg} \times \mathrm{Rp} 4.000,-/ \mathrm{kg} & =\mathrm{Rp} .97 .675 .200,- \\ >\text { Yogyakarta } & =5.462,1 \mathrm{~kg} \times \mathrm{Rp} 4.000,-/ \mathrm{kg} & =\mathrm{Rp} .21 .848 .400,- \\ >\text { Jawa Timur } & =175.108,5 \mathrm{~kg} \times \mathrm{Rp} .4 .000,-/ \mathrm{kg} & =\mathrm{Rp} .700 .434 .000,-\end{array}$

Dengan demikian apabila limbah fleshing ini benar-benar digunakan sebagai alternatif sumber bahan baku lemak untuk pembuatan sabun mandi, maka di berbagai wilayah tersebut akan mempunyai nilai tambah dari hasil produksi sabun mandi, yang besarnya berkisar antara 21-700 juta rupiah, sekaligus juga memecahkan masalah pencemaran lingkungan.

\section{KESIMPULAN}

1. Sisa fleshing bisa digunakan sebagai bahan alternatip/sumber lemak untuk pembuatan sabun mandi yang dapat memenuhi SNI 06-3532-1994.

2. Pemanfaatan sisa fleshing berarti membantu memecahkan masalah pencemaran lingkungan.

3. Besarnya nilai dari hasil produksi lemak di berbagai wilayah (Jabotabek, Jabar, Jateng, DIY, Jatim), berkisar antara 6 juta - 200 juta rupiah per tahun.

4. Besarnya nilai dari hasil produksi sabun di berbagai wilayah (Jabotabek, Jabar, Jateng, DIY, Jatim), berkisar antara 21 - 700 juta rupiah per tahun.

\section{SARAN}

1. Limbah padat yang berupa sisa fleshing sebaiknya jangan dibuang begitu saja karena fleshingnya bisa untuk makanan ternak, sedangkan lemaknya bisa dimanfaatkan antara lain untuk bahan pembuatan sabun.

2. Penelitian ini bisa dikembangkan untuk pembuatan produk lain, misal: minyak untuk proses penyamakan kulit. 


\section{DAFTAR PUSTAKA.}

Bailey, A.E., 1945. Industrial Oil and Fat Products. Interscience Publishers, Inc. - New York, N.Y. (Hal. 4-24; 37 - 70; 106 - 18).

Brotomulyono, Arum Yuniari, H. Surip, P. Setyowati, Nadilah dan Alip, 1986. Laporan Penelitian Konversi Kulit Sapi, Kerbau, Kambing, dan Domba Mentah Menjadi Kulit Tersamak Ditinjau dari Parameter Prosesnya Sebagai Produk Perdagangan. BBKKP. Team 2.9/Proy.PPIKKP/ 85-86.

Diyono, 1999. Market Survey on Leather Industry in Indonesia. Based on Agreement for Market Survey between Unione Nazionale Industria Coniaria (UNIC), Milano, Italia and Mr. Diyono Hening Sasmito, Yogyakarta, Indonesia by Contract No. A.61/B7/301/95/108-35. Yogyakarta Cec. 31,1999 .

Made Suladra 1992. Industri Kimia II. Petunjuk Praktikum. Departemen Perindustrian dan Perdagangan RI. Pusat Pembinaan Pelatihan Ketrampilan dan Kejuruan Sekolah Menengah Teknologi Industri. (Hal.25 - 31).

Priambodo, A. 2000. Tugas akhir berjudul: Pabrik Sabun Mandi dari Palm Kernel Oil dengan Proses Mazzoni -SCN. Fak. Teknologi Industri Institute Teknologi Sepuluh Nopember Surabaya. (Hal. 2 - 5 ).

Rahcmadinata, E. 2000. Tugas akhir berjudul: Pabrik Sabun Mandi dari Crude Palm Oil dengan Proses Hidrolisa. Fak. Teknologi Industri Institute Teknologi Sepuluh Nopember Surabaya. (Hal. 2 - 5).

Shereve, R., 1967. Chemical Process Industries. McGraw-Hill Kogakusha, LTD. Tokyo Dusseldorf Johannesburg London Mexico. (Hal. 523 - 569).

SNI 06-3532-1994. Sabun Mandi. Dewan Standardisasi Nasional - DSN.

Sutyasmi, Ign. Sunaryo, Widari, 2001. Laporan Akhir tentang Pemanfaastan Lemak Fleshing untuk Sabun. Team Proyek 016301 A. PPTIKKP. BBKKP, Yogyakarta. 